in the British Museum (Natural History), and in view of the importance of the entomological papers in the Annals, Mr. E. B. Britten, of the Department of Entomology at the British Museum, is also to join the board. Biologists will welcome the extension of the field of this old-established journal and wish it a new lease of life.

\section{Forty Years of X-Ray Diffraction: Anniversary Meeting in London}

THE X-Ray Analysis Group of the Institute of Physics is holding a meeting at the Royal Institution, Albemarle Street, London, W.1, during October 24-25, in celebration of the fortieth anniversary of the discovery of $\mathrm{X}$-ray diffraction by Friedrich, Knipping and von Laue (see Nature, June 7, p. 949). After an opening historical address by Sir Lawrence Bragg, four papers will be read: "The Growth and Scope of X-Ray Crystal Analysis", by Prof. J. D. Bernal ; "Chemical Problems", by Dr. D. Hodgkin; "X-Ray Analysis and the Metallic State", by Prof. G. V. Raynor; and "The Application of X-Ray Analysis to Protein Structure", by Sir Lawrence Bragg. A commemorative dinner will be held on October 24, in the Criterion Restaurant, Piccadilly Circus, at which the guests of honour will be Prof. M. von Laue and Prof. J. M. Bijvoet. During the two days of the meeting there will be an exhibition in the Royal Institution of historical X-ray apparatus, etc. The meeting is open to all. Application forms for attendance (to be returned by September 20) and further information can be obtained from the Deputy Secretary of the Institute of Physics, 47 Belgrave Square, London, S.W.1.

\section{Royal Photographic Society: Annual Exhibition}

TEE ninety-seventh annual exhibition of the Royal Photographic Society will be opened by the American Ambassador, Mr. W. S. Gifford, on September 11, in the Society's House, 16 Princes Gate, London, S.W.7. It will be open to the public without charge from September 12 until October 12, inclusive, from 10 a.m. to 8 p.m. each day (Saturdays, 10 a.m. 5.30 p.m. ; Sundays, $2.30-5.30$ p.m.). After the London display, the whole of the exhibition will be transferred to Leeds for the period October 25November 23, and to Bristol for the period December 6-31.

\section{Foot-and-mouth Disease Inquiry}

THE Minister of Agriculture and Fisheries has appointed a committee to review the policy and arrangements for dealing with foot-and-mouth disease in Great Britain, and to advise whether any changes should be made in the light of present scientific knowledge and the technical and administrative experience gained in recent years in this and other countries. The Committee is constituted as follows: Sir Ernest Gowers (chairman), Prof. E. D. Adrian, Colonel H. Cator, Dr. Ll. Wyn Griffith, Lord Hungarton, Prof. A. Robertson, A. R. Semple, and $H$. Woolley. R. A. Thorne, of the Ministry of Agriculture and Fisheries, has been appointed secretary to the Committee. Communications should be addressed to him at Hook Rise, Tolworth, Surbiton, surrey.

\section{Rajasthan Academy of Sciences : Officers}

At the second annual meeting of the Rajasthan Academy of Sciences, Pilani, the following officers were elected : President, Dr. G. S. Mahajani, vice- chancellor, University of Rajputana; Vice-Presidents, Dr. N. N. Godbole, director of industries and commerce, Rajasthan Government, and Dr. A. Mookerji, professor of physics, Birla College of Sciences; Secretary, K. Ramamurti, Birla College of Science, Pilani. Mr. M. L. Schroff and I)r. M. L. Roonwal, as ex-presidents of the Academy, serve as vice-presidents, and Mr. Roshan Singh continues to be the treasurer.

\section{Announcements}

A DIscussion on "The Place of the Scientist in Civil Defence" has been arranged by the Royal Institute of Chemistry (London and South-Eastern Counties Section) with the Institute of Biology and the Institute of Physies (London and Home Counties Branch) and will be held on October 16 at 6.30 p.m. in the City of London School, Victoria Embankment, London, E.C.4. The principal speakers will be: Sir John Hodsall, Sir Charles Ellis, Dr. E. T. Paris, Prof. W. V. Mayneord and Prof. H. N. Rydon.

A seminar on polymer science is to be held in the Department of Chemistry, University College, London, W.C.l, during the autumn term. Eight lectures, by different speakers, will be given on Fridays at 4.30 p.m., beginning October 17. Visitors will be welcome.

A CONFERENCE on the "Growth of Protozoa" will be held during October 24-25 at the New York Academy of Sciences under the joint sponsorship of the Academy and the Society of Protozoologists. The first day will be devoted to free-living forms, and the second to parasites. The programme is designed to be of broad biochemical, morphological and medical interest. The proceedings will be published in the Annals of the Academy. Further information can be obtained from the secretary of the Society, Prof. E. R. Becker, Department of Zoology and Entomology, Iowa State College, Ames, Iowa.

Trie Sixth Congress of the International Scientific Film Association will be held in the Maison de la Chimie, 28 rue St. Dominique, Paris $7^{\mathrm{e}}$, during September 23-October 1. During the Congress there will be meetings of the General Assembly of the International Scientific Film Association, meetings of the permanent committees dealing respectively with medical, research, technical and industrial films, and a festival of scientific films. At the Congress Great Britain will be represented by the British Scientifio Film Association, and further information can be obtained from the administrative officer of the Association at 164 Shaftesbury Avenue, London, W.C.2.

TeE Council of the City and Guilds of London Institute has conferred the fellowship of the Institute on the following past students of the City and Guilds College: L. H. Bedford, chief television engineer, Marconi's Wireless Telegraph Co., Ltd.; H. F. Cronin, chief engineer, Metropolitan Water Board; W. A. Del Mar, chief engineer, Habirshaw Cable and Wire Division, Phelps Dodge Copper Products Corp., United States; H. J. B. Harding, director, John Mowlem and Co., Ltd., and also of Soil Mechanics, Ltd. ; W. H. G. Roach, managing director, William Press and Son, Ltd., technical director, D. and $\mathrm{C}$. and William Press, Ltd., director of the General Descaling Co., Ltd., and also of John Paul and Co., Ltd., Dublin. 